\title{
Article
}

\section{Zero Carbon Building Practices in Aotearoa New Zealand}

\author{
Thao Thi Phuong Bui ${ }^{1, *}$, Suzanne Wilkinson ${ }^{1}$, Niluka Domingo ${ }^{1}$ and Casimir MacGregor ${ }^{2}$ \\ 1 School of Built Environment, Massey University, Auckland 0632, New Zealand; \\ S.Wilkinson@massey.ac.nz (S.W.); N.D.Domingo@massey.ac.nz (N.D.) \\ 2 Building Research Association of New Zealand, Judgeford, Porirua 5240, New Zealand; \\ casimir.macgregor@branz.co.nz \\ * Correspondence: T.Bui@massey.ac.nz; Tel.: +64-272618906
}

check for updates

Citation: Bui, T.T.P.; Wilkinson, S.; Domingo, N.; MacGregor, C. Zero Carbon Building Practices in Aotearoa New Zealand. Energies 2021, 14, 4455. https://doi.org/10.3390/ en14154455

Received: 22 June 2021

Accepted: 21 July 2021

Published: 23 July 2021

Publisher's Note: MDPI stays neutral with regard to jurisdictional claims in published maps and institutional affiliations.

Copyright: (c) 2021 by the authors. Licensee MDPI, Basel, Switzerland. This article is an open access article distributed under the terms and conditions of the Creative Commons Attribution (CC BY) license (https:/ / creativecommons.org/licenses/by/ $4.0 /)$.

\begin{abstract}
In the light of climate change, the drive for zero carbon buildings is known as one response to reduce greenhouse gas emissions. Within New Zealand, research on climate change mitigation and environmental impacts of buildings has received renewed attention. However, there has been no detailed investigation of zero carbon building practices. This paper undertakes an exploratory study through the use of semi-structured interviews with government representatives and construction industry experts to examine how the New Zealand construction industry plans and implements zero carbon buildings. The results show that New Zealand's construction industry is in the early stage of transiting to a net-zero carbon built environment. Key actions to date are focused on devising a way for the industry to develop and deliver zero carbon building projects. Central and local governments play a leading role in driving zero carbon initiatives. Leading construction firms intend to maximise the carbon reduction in building projects by developing a roadmap to achieve the carbon target by 2050 and rethinking the way of designing and constructing buildings. The research results provide an insight into the initial practices and policy implications for the uptake of zero carbon buildings in Aotearoa New Zealand.
\end{abstract}

Keywords: zero carbon; net-zero carbon; zero energy; low carbon; carbon emissions; carbon reduction; climate change

\section{Introduction}

Climate change is one of the biggest environmental challenges facing the world. As instigated by the United Nations Framework Convention on Climate Change, Paris Agreement, signed in 2016; this attempts to limit global warming to no more than $1.5^{\circ} \mathrm{C}$ above pre-industrial levels [1]. To ensure that global warming does not exceed the $1.5^{\circ} \mathrm{C}$ threshold, greater carbon reduction needs to be achieved [2]. In the New Zealand context, the Aotearoa New Zealand Government passed the Climate Change Response (zero carbon) Amendment Act 2019, which ratified the Paris Agreement and set carbon budgets to enable the country to transition to net-zero carbon by 2050 [3].

The construction industry offers potential for reducing greenhouse gas emissions $[4,5]$. The construction industry makes up more than $40 \%$ of the global energy use, which contributes to operational carbon emissions, and one-third of worldwide greenhouse gas emissions [4,6]. In New Zealand, the building and construction sector accounts for around $20 \%$ of New Zealand's greenhouse gas emissions, considering all the materials used by the sector [7]. As the construction industry contributes significantly to tackle climate change impacts, the Ministry of Business, Innovation, and Employment (MBIE) has launched the "Building for Climate Change Programme" in 2020, seeking to reduce building emissions while also improving building resilience to climate change. The programme aims to transform the industry to reduce emissions by making changes to the building code to raise minimum requirements and enhance the system operation [7]. The application of zero carbon buildings is, therefore, fast becoming a key requirement $[8,9]$. This research 
applies the concept of zero carbon building that aims to achieve the highest level of carbon reduction from both the operation stage and embodied carbon of materials throughout the whole life cycle of the building.

There is a growing body of international literature that recognises the significance of zero carbon buildings in many aspects. On the one hand, Jones et al. [10] explore zero carbon design for non-domestic buildings in Europe, concluding that integrating smart facades, ventilation, and surface heating and cooling is possible for achieving low to zero energy buildings. Moschetti et al. [11] adopted a broader perspective that it is challenging to achieve a full compensation of the life cycle greenhouse gas emissions from materials by offsetting through renewable energy, even with extensive use of PV panels, especially in a low-carbon grid situation as in Norway. As such, focusing on the embodied energy and emissions of materials is a strategic pathway in transiting from zero energy to zero emission buildings.

On the other hand, system boundaries, clusters, and exemplars of zero carbon buildings in Hong Kong are introduced in the studies [12,13]. In the same vein, Pan and Pan [9] investigate stakeholder knowledge, attitude, and practice for zero carbon buildings in a systems manner. The conclusion is the distinction existing between different stakeholder groups regarding their knowledge. This result underlines that explicit zero carbon building knowledge plays a crucial role in generating a knowledge-induced attitude that advocates changes in zero carbon building practice. In the case of business model, Zhao et al. [14] develop a typology of business model innovations for implementing zero carbon buildings from developers' and clients' perspectives by theoretically analysing five zero carbon building projects in Australia, Japan, Hong Kong, Singapore and the UK. The research findings support business solutions for successfully achieving zero carbon building projects.

Despite the increased global interest in zero carbon buildings, there is a lack of research published on this field in New Zealand. Based on the Scopus and Web of Science database, only four journal papers focusing on climate change mitigation and the environmental impacts of buildings in New Zealand are available when searching with the keywords ("climate change mitigation" and "building" or "construction" and "New Zealand"). Whereas, no papers mention the application of zero carbon buildings in New Zealand with key words ("zero carbon" or "low carbon" and "building" or "construction" and "New Zealand"). Although no previous study has investigated the adoption of zero carbon buildings in detail, the current research on climate change and buildings within New Zealand provide the knowledge foundation, contributing to the future development of zero carbon buildings. For example, Chandrakumar et al. [13] devise a science-based approach that determines a building carbon budget based on the global climate target of limiting global warming to below $1.5^{\circ} \mathrm{C}$. The results help to define the boundaries for zero carbon buildings in New Zealand. Ghose et al. [14] are much more concerned with the feasible environmental impacts associated with the energy-efficient refurbishment of New Zealand's pre-existing office building stock. The main finding offers practical implications for reducing carbon emissions in building refurbishment. It is suggested that adopting efficient resource use and waste management solutions decreases carbon emissions without increasing environmental impacts. In a study reported to the government, MacGregor et al. [15] identify financial constraints, skills and knowledge shortage, lack of legislation and slow innovation as the main industry barriers to zero carbon buildings in New Zealand. However, due to the use of a literature review, the study is limited to the construction industry views on zero carbon buildings. Therefore, there is a need for further in-depth research on the application of zero carbon buildings in the New Zealand context.

This paper aims to investigate the current practices of zero carbon buildings within the New Zealand construction industry from the government and construction industry experts' perspectives. The term "zero carbon building" also refers to "building towards net-zero carbon" or "net-zero carbon building". The paper describes the methodology applied in the research and then reports the research results and analysis according to four main themes: (1) the concept of zero carbon building; (2) government initiatives; 
(3) industry engagement; (4) assessment methods and tools. Finally, the paper further discusses the significant influence of the government and policy implications for the uptake of zero carbon buildings in New Zealand.

\section{Materials and Methods}

Semi-structured interviews with government representatives and construction industry experts were carried out to understand the implementation of zero carbon buildings in New Zealand. A qualitative approach utilising semi-structured interviews was chosen as it allowed probing of views and opinions and participants were encouraged to expand their answers [15,16], leading to interesting or unexpected participants' viewpoints about the issue of climate change and the construction industry in New Zealand. Multi-purposive sampling techniques including sampling to achieve representativeness and sequential sampling were used to select participants $[17,18]$. The expert sampling was used to ensure the desirable criteria while the snowball sampling approach was applied due to the shortage of construction experts who had knowledge and experience in sustainable construction. Participants were required to work within the New Zealand construction industry for at least 5 years and have expertise on sustainable construction and carbon reduction for buildings. Initial interviewees were identified through professional references and LinkedIn-a professional networking tool that offered a large-scale database of business professionals [19], then these interviewees provided suggestions to locate further participants.

Between December 2020 and February 2021, 11 interviews were undertaken, including 4 in-person and 7 online interviews, ranging from $30 \mathrm{~min}$ to $1 \mathrm{~h}$. The interviewees came from the three biggest New Zealand local governments, one national housing association, one non-profit building organisation, three large construction firms and three small-tomedium construction enterprises. An overview of the participants' profiles is illustrated in Table 1, including the codes used later in the paper to report the findings. This study was an exploratory and/or phenomenological research to offer an insight into the problem rather than grounded theory research. According to Creswell and Poth [20], a grounded theory required interviews with 20-30 participants, while there was a need for up to 10 people in phenomenological research. Francis et al. [21] also recommended that the initial analysis sample was 10 interviews; after that, one or two further interviews were conducted to confirm no new themes emerging. Thus, the sample size in this research was considered sufficient when achieving the saturation point of the data, which was reached after interviewing 9 participants.

Table 1. Participants' demographics.

\begin{tabular}{cccc}
\hline Participants & Position & Type of Organisation & Organisation Code \\
\hline$\# 1$ & Local government representatives & Local government & $\mathrm{A}$ \\
$\# 2$ & Local government representatives & Local government & $\mathrm{B}$ \\
$\# 3$ & Local government representatives & Local government & $\mathrm{C}$ \\
$\# 4$ & Sustainability Manager & Architecture \& Design & $\mathrm{D}$ \\
$\# 5$ & Senior Architect & Architecture \& Design & $\mathrm{E}$ \\
$\# 6$ & Penior Project Manager & Project Management & $\mathrm{F}$ \\
$\# 7$ & Technical Director & Architecture \& Design & $\mathrm{G}$ \\
$\# 8$ & Senior Architect & Architecture \& Design & $\mathrm{H}$ \\
$\# 9$ & Senior Architect & $\mathrm{I}$ & $\mathrm{J}$ \\
$\# 10$ & Senior Manager in Building and Communities & Non-profit building organisation & $\mathrm{K}$ \\
$\# 11$ & Carbon Neutral Housing Manager & Housing Association & \\
\hline
\end{tabular}


The interviews were digitally recorded subject to the participant's permission. Data collected from interviews were analysed using thematic analysis, which was known as a foundational method for qualitative analysis. Thematic analysis not only organised and described data in rich detail but also interpreted various aspects of the research topic [22,23]. Following step-by-step guidance demonstrated by Clarke and Braun [23], the digitally recorded interviews were transcribed then analysed using NVivo 12. NVivo software was highly recommended by international researchers because it opened up new ways of determining the missing data when managing the information without software, and generated efficient, multiple and transparent data analysis [24,25]. Overall, four broad themes emerged from the data analysis: the concept of zero carbon building; government initiatives; industry engagement and assessment methods and tools.

\section{Results}

\subsection{The Concept of Zero Carbon Buildings in New Zealand}

Several definitions of zero carbon buildings were proposed globally, examples included near-zero energy, zero energy, zero carbon, net-zero carbon [26]. To classify the meaning of zero carbon building, Pan [12] suggested a model using two fundamental dimensions of zero carbon building's concept. According to this model, the terms "zero carbon building" and "zero energy building" considered the entire life cycle grouped in the general context, and the carbon/energy aspect, in comparison to "green building", which was categorised in the holistic sustainability aspect. However, the term "zero carbon building" was often conflated with "zero energy buildings", notwithstanding the difference between these two concepts. Zero energy building indicated the lowest level at which the onsite renewable energy generation compensated for the emissions related to all energy use during operation. To achieve the highest zero carbon level, the carbon emissions of locally generated energy from renewable sources, such as photovoltaic (PV) panels, solar thermal, heat pump, or combined heat and power (CHP) technologies, must counterbalance the embodied emissions from materials. For that reason, both efforts on energy-related measures and a holistic focus on how to reduce the embodied emissions of the materials during the entire life cycle were required for the transition from a "zero energy building" to a "zero carbon building" [11].

Since the meaning of zero carbon building defined in building regulations and policies might be different among countries, critical questions asked were, what was the highest level of carbon reduction? and, what carbon performance benchmarks were required for a zero carbon building in New Zealand? As mentioned in [27], there was potential for the use of carbon budgets for individual buildings to help define the carbon performance goal for zero carbon buildings. The global climate target was limiting global warming to below $1.5^{\circ} \mathrm{C}$ or $2{ }^{\circ} \mathrm{C}$ and the global carbon budget was subsequently translated from the global climate target for the period of 2018-2050 [2]. For instance, a New Zealand detached house has a carbon budget of 55,280 $\mathrm{kg} \mathrm{CO}_{2}$ eq. This view was also supported by one interviewee (\#11), who proposed that there should be a comprehensible roadmap towards zero carbon buildings for the New Zealand building sector. The first step was getting New Zealand's buildings to meet the global climate target and carbon budget by 2030-2035. Then, the net-zero carbon target for buildings by 2050 can be achieved onwards (see Figure 1). One implication is that policymakers can adopt the use of carbon budgets for individual buildings, to help create carbon performance benchmarks and sketching a well-defined roadmap for achieving zero carbon buildings in New Zealand. 


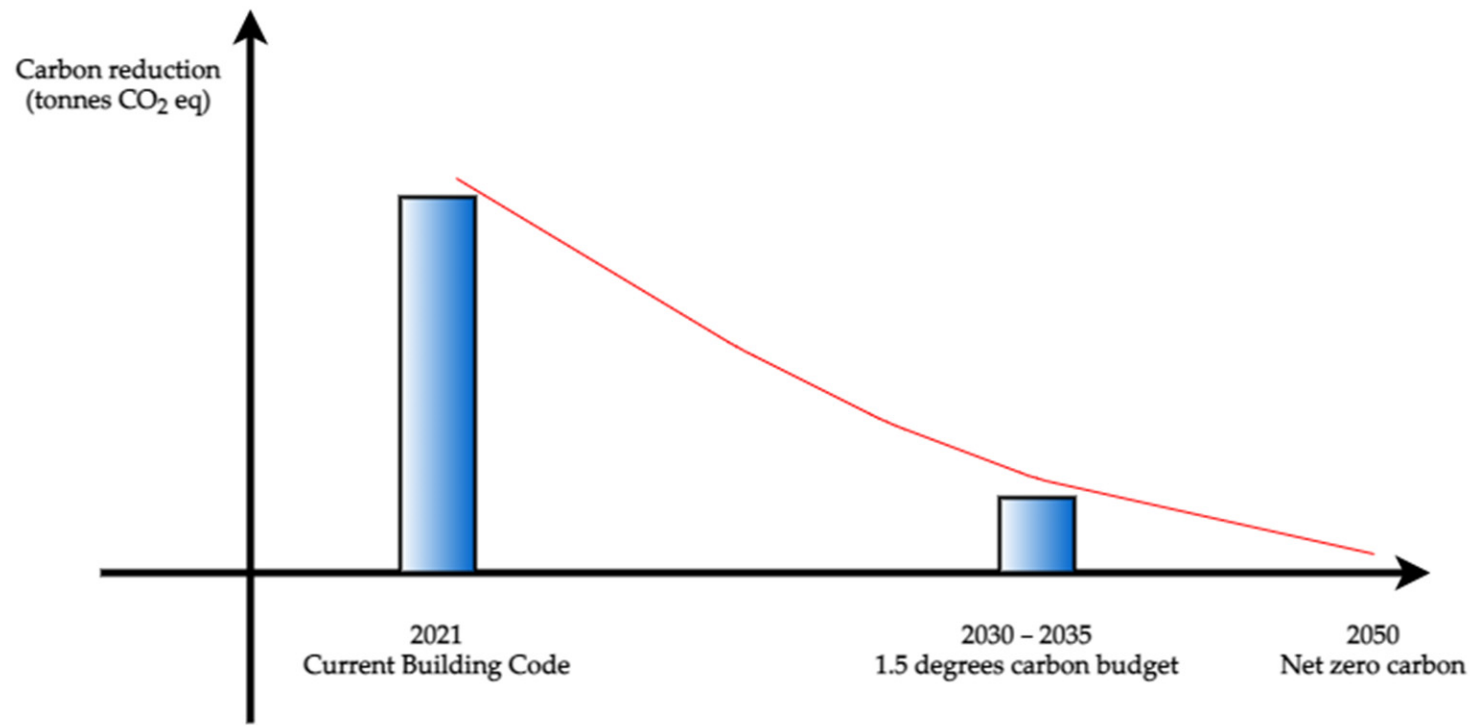

Figure 1. A proposed roadmap towards zero carbon buildings for the New Zealand construction industry (Author's source).

\subsection{Government Initiatives}

\subsubsection{Central Government Initiatives}

To tackle climate change within the building sector, the Ministry of Business, Innovation and Employment (MBIE) — a central government agency has launched the "Building for Climate Change" programme [7]. The government suggested two ways to reduce emissions of buildings: (1) set minimum levels of operational efficiency for new buildings and (2) set limits for the amount of embodied carbon in new buildings. For example, the government set the operational emissions cap goals for the New Zealand building sector by 2035 (see Figure 2), in which, the operational cap had requirements for fossil fuel combustion, electricity use and water use. Initial, intermediate and final operational emissions caps were the targets that all new buildings must meet at consent and code compliance stages. However, critics question how the government has come up with carbon reduction targets for new buildings. Furthermore, the government strategy focused on new builds only, given that refurbishing the existing building stock to be net-zero carbon has been neglected. Several studies on climate change impacts of buildings in New Zealand emphasised the need to prioritise existing buildings. For example, pre-existing detached houses contributed $66 \%$ of the climate impact while the figure for new-built ones was $34 \%$ [27]. A life cycle assessment of an office building in Wellington showed that the refurbishment building saved approximately 3100 tonnes of carbon emissions compared to a new reference building [28]. Even though the government claimed that enhancing the climate efficiency of new buildings would guarantee New Zealand to be on track for the 2050 goals, the priority for building refurbishment towards net-zero carbon should be placed in the government's climate change plan.

Two mitigation frameworks that address transforming operational efficiency and whole-of-life embodied carbon emissions reduction were introduced in the programme. Commenting on these two frameworks, including "Whole-of-Life Embodied Carbon Emissions Framework" and "Transforming Operational Efficiency Framework", a local representative (\#1) reported that the former document was related to embodied carbon emissions, which stated how the regulation went to segment but did not specify the attainable targets. While the latter one was straightforward to follow, as it set clear goals and the ways to implement the operational efficiency of buildings, and this policy document considered not only energy efficiency but also water efficiency. The operational carbon reduction target could be reached following the "Transforming Operational Efficiency Framework", however, the gap concerning the embodied carbon reduction remains, requiring the central government to take action to obtain the overall net-zero carbon goal for buildings. The 
study [27] recommended that carbon reduction in the operational use stage could be accomplished if technological and systemic building changes were supported by policy and regulation. However, recent overseas studies $[29,30]$ underlined the urgent requirement to reduce embodied carbon emissions of buildings overseas. An achievable goal and clear protocol, which addresses the embodied carbon reduction of buildings, therefore, is needed to improve the "Whole-of-Life Embodied Carbon Emissions Framework".

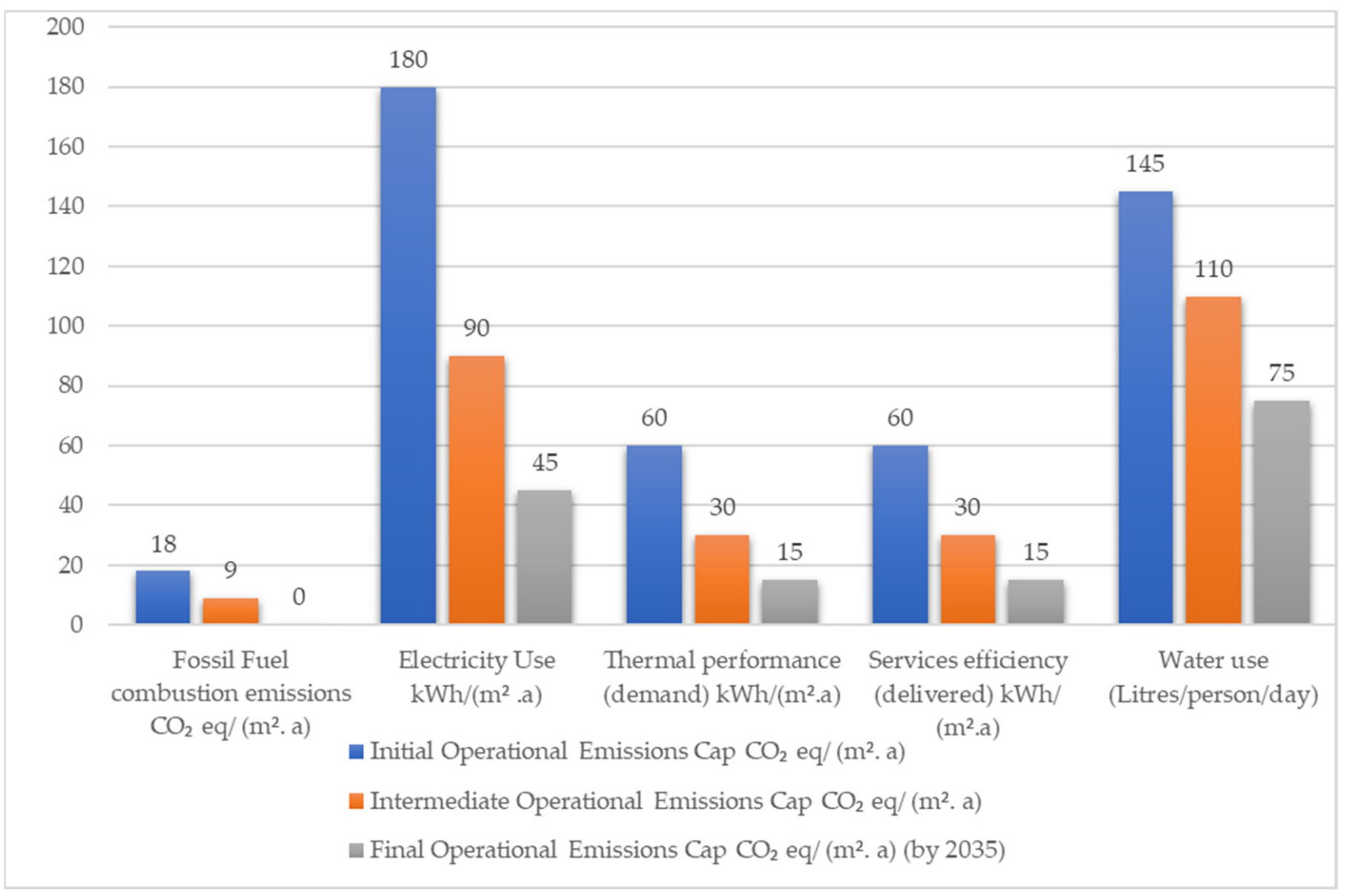

Figure 2. Operational Emissions Cap goals for the New Zealand building sector by 2035 (Source: [7]).

Another major government initiative towards the net-zero carbon target for buildings was requiring the public sector to be carbon neutral by 2025 [31]. The government made the climate declaration in late 2020 and would lead by example by getting government's buildings in order [32]. However, concern was expressed about the slow take-up of reducing carbon emissions in public buildings due to the small proportion of existing office buildings considered in this announcement, for only buildings with new leases in 2021. It was proposed that the government should commit when they build and operate their building stock including public housing, schools and hospitals, and use available methodologies to allow those buildings to be energy-efficient and low-carbon [32]. Consistent with Ball et al. [33], who evaluated the issues for the carbon-neutral public sector, this result indicated that the government should contemplate an intelligible implementation process as well as effective evaluation of the "leading by example" in transiting the public building sector to be carbon neutral by 2025 .

The government has worked closely with the construction industry, other government agencies, key stakeholders, local government, and communities to ensure New Zealand's building sector achieve the net-zero carbon target by 2050 . However, further work such as formulating net-zero carbon building regulations and guidelines are required to be done. Without central government encouragement, overall, carbon reduction activities might not be planned and implemented effectively $[34,35]$. 


\subsubsection{Local Government Initiatives}

As stated by interviewee \#2, local government A launched a comprehensive climate plan, seeking to reduce greenhouse gas emissions by $50 \%$ by 2030 and achieve net-zero emissions by 2050. Of which, specific actions such as sustainable design and construction, retrofitting buildings, minimising construction and demolition waste, etc., were proposed for the built environment sector. Interviewee \#2 also revealed that a new minimum beyond building code for renewal works over $\$ 2$ million was set to deliver a sustainable asset standard because the assets accounted for $75-80 \%$ of the local government A's total carbon footprint. Another participant (\#1) indicated that local government B planned a common policy within the organisation and the building sector. Two main programmes, named "Eco design advice" and "Targeting net-zero carbon" would be executed in the next couple of years. These programmes considered carbon reduction for the whole life cycle of buildings, one focused on building in general including new builds and refurbishment, whereas the other was designed for building maintenance, energy use, recycling waste, etc. In comparison to $\mathrm{A}$ and $\mathrm{B}$, local government $\mathrm{C}$ did not have an official policy for buildings, but a business case, working on an environmentally sustainable design policy for local government C's assets, was expected to be released in 2021, which set certain standards for new builds and refurbishing projects (\#3). Referring to the housing association, representative (\#11) specified that organisation $\mathrm{K}$-a public housing corporation that delivers the government's priorities for housing and urban development in New Zealand, was working towards delivering against the "Building for Climate Change" programme. However, detailed strategies for addressing the net-zero carbon target for housing projects had not been officially announced.

The critical observation is that local government strategies consist of reducing carbon emission for both new and pre-existing buildings in comparison to the central government "Building for Climate Change" plan mentioned in Section 3.2.1. The summary of government initiatives towards net-zero carbon buildings is illustrated in Table 2. According to the findings, we could infer that New Zealand's local government and public housing agency are planning and implementing the greatest carbon reduction goal for public buildings, following the central government initiatives with the requirements for the public sector.

Table 2. A summary of government initiatives towards net-zero carbon buildings in New Zealand.

\begin{tabular}{|c|c|c|c|c|}
\hline & Initiatives & Classification & Scope of Work & Applicable Areas \\
\hline \multirow{2}{*}{$\begin{array}{c}\text { Central } \\
\text { government }\end{array}$} & $\begin{array}{l}\text { Building for Climate } \\
\text { Change programme }\end{array}$ & $\begin{array}{l}\text { National building } \\
\text { regulations and } \\
\text { guidelines }\end{array}$ & $\begin{array}{l}\text { Setting operational and } \\
\text { embodied carbon reduction } \\
\text { targets for buildings }\end{array}$ & New buildings \\
\hline & $\begin{array}{l}\text { The public sector to be } \\
\text { carbon neutral by } 2025\end{array}$ & National policy & $\begin{array}{c}\text { Mandating energy efficiency } \\
\text { standards for government office } \\
\text { buildings }\end{array}$ & $\begin{array}{c}\text { New and existing } \\
\text { buildings }\end{array}$ \\
\hline \multirow{5}{*}{$\begin{array}{l}\text { Local } \\
\text { government }\end{array}$} & $\begin{array}{l}\text { Local government A's } \\
\text { climate change plan }\end{array}$ & $\begin{array}{l}\text { Local government } \\
\text { policy }\end{array}$ & $\begin{array}{l}\text { Sustainable design and } \\
\text { construction, retrofitting } \\
\text { buildings, minimising } \\
\text { construction and demolition } \\
\text { waste, etc. }\end{array}$ & $\begin{array}{c}\text { New and existing } \\
\text { buildings }\end{array}$ \\
\hline & $\begin{array}{l}\text { Local government A's new } \\
\text { policy for renewal work }\end{array}$ & $\begin{array}{l}\text { Local government } \\
\text { policy }\end{array}$ & $\begin{array}{c}\text { Delivering sustainable asset } \\
\text { standards }\end{array}$ & Existing buildings \\
\hline & $\begin{array}{l}\text { Local government B's } \\
\text { climate change plan }\end{array}$ & $\begin{array}{l}\text { Local government } \\
\text { policy }\end{array}$ & $\begin{array}{l}\text { Improving whole-of-life carbon } \\
\text { reduction for buildings }\end{array}$ & $\begin{array}{c}\text { New and existing } \\
\text { buildings }\end{array}$ \\
\hline & $\begin{array}{l}\text { Local government C's } \\
\text { sustainable design policy }\end{array}$ & $\begin{array}{l}\text { Local government } \\
\text { policy }\end{array}$ & $\begin{array}{l}\text { Setting standards for building } \\
\text { projects }\end{array}$ & $\begin{array}{c}\text { New and existing } \\
\text { buildings }\end{array}$ \\
\hline & $\begin{array}{l}\text { Housing association's } \\
\text { climate change plan }\end{array}$ & Social housing policy & Upcoming & Housing projects \\
\hline
\end{tabular}

Notwithstanding the capability of managing municipal building's carbon footprint, the local governments have only a few chances to influence the construction industry 
in maximising carbon reduction. Local governments could be ahead of the curve and a showcase model for the private sector. However, they were limited in being able to encourage the construction industry to construct high-performance buildings, as stated, "We do not have the ability to require people to build beyond the code" (\#3).

The present results are significant in at least two major aspects. Firstly, there are local government's financial constraints in the view of net-zero carbon policies for buildings. Even though the central government has a strong will of building towards net-zero carbon, the local governments may not be able to entirely execute this because of insufficient local government finances. The findings reported are in line with an existing study of Zhang et al. [36], which finds that the financial constraint of local government can lead to poor implementation of low-carbon building policies in China. Secondly, while local governments continue with ongoing efforts begun during their participation in the "Building for Climate Change" programme, carbon reduction actions may only persist in a scaled-back manner if lacking the assist of the central government. The Communities for Climate Protection-New Zealand (CCP-NZ) program also highlights the important role of the central government in supporting local government to carbon management activities [37].

\subsection{Industry Engagement}

Whilst the government planned on building for net-zero carbon, the construction industry took direct responsibility for developing and delivering zero carbon buildings. To explore the actions that the construction industry has carried out on building projects, building experts were asked to indicate how zero carbon build had impacts on construction firms and building projects in New Zealand. Among construction companies' representatives, the majority confirmed that their organisations are committed to reducing carbon emission throughout organisations' policies. Participant \#4 said that organisation D-a leading architecture firm in sustainable design, set goals for decreasing whole of life carbon by $50 \%$ by 2030 from the current benchmark. The details of organisation D's strategies on carbon reduction are illustrated in Figure 3. Similarly, organisation I also planned for its carbon reduction actions by establishing zero carbon policy, as specified, "We are also committing on our website, by 2030 to make our buildings zero carbon building rated" (\#9).

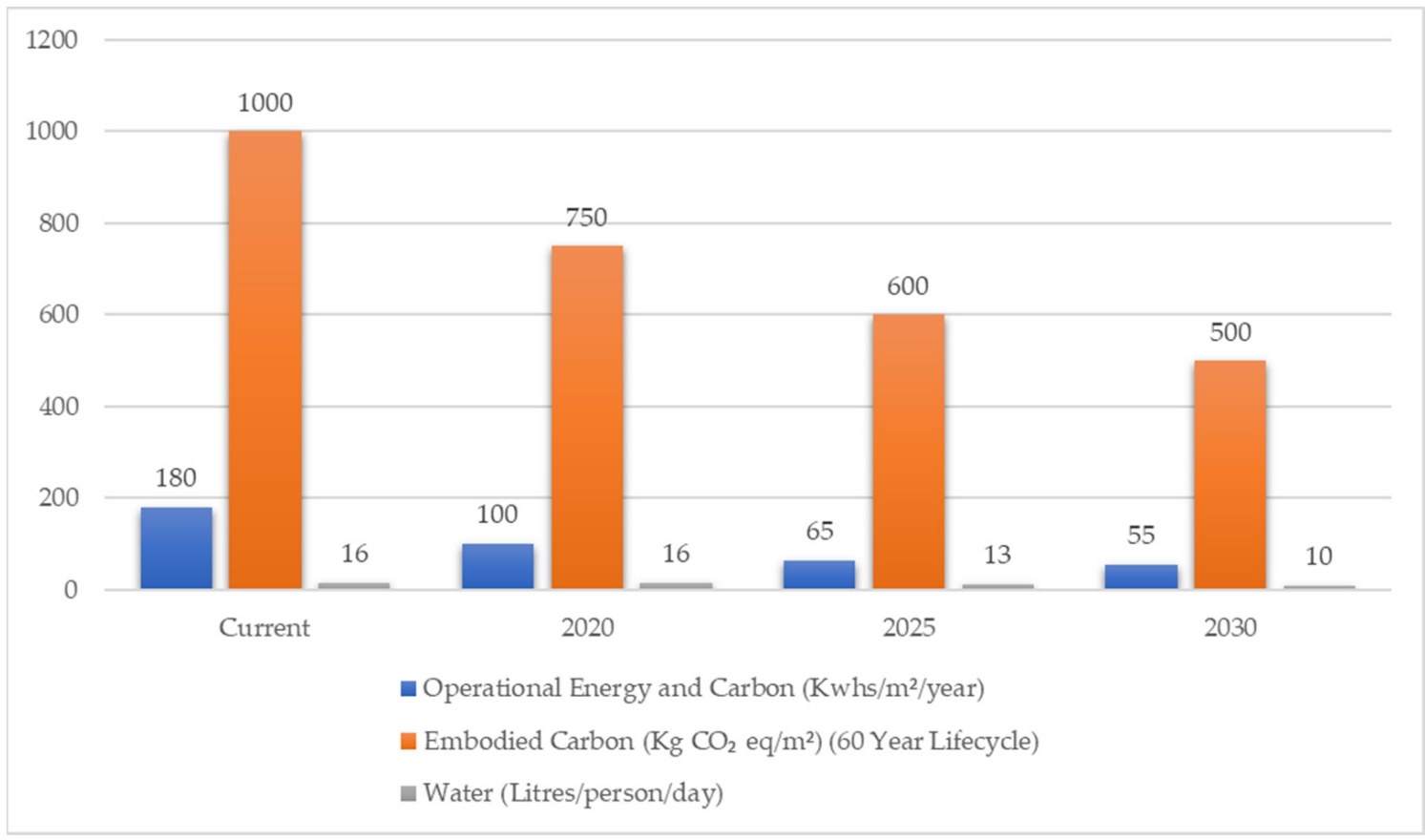

Figure 3. Organisation D's pathway to net-zero carbon design (Source: Organisation D). 
From small to medium-sized enterprises' perspectives, one reported that their companies did not have a defined policy, but they started looking at ways to improve the overall carbon performance for their construction projects (\#5). Leading and large construction firms employed the carbon reduction target in their organisations and building projects while small to medium-sized enterprises only focused on changing the way of thinking to enhance the general practices.

This finding supports the existing literature in low-carbon innovations and small to medium-sized enterprises. Small construction firms operate differently from large firms in relation to construction innovation processes [38,39]. Due to the lack of resources, knowledge and skills, it can be challenging for small to medium-sized enterprises when adopting low-carbon innovations for building projects. Thus, more support such as knowledge development and vocational training in low-carbon innovations should be given for small to medium-sized enterprises [40,41].

Another question considered was what could help the industry to build zero carbon buildings. The most common agreement was that the government should take a lead and upgrade the building code and regulations. Half of the interviewees suggested that the government should make changes to the building code and regulations, "If you want something to happen, you basically got to make it compulsory" (\#5), while others believed that the government must commit to leading by example and support all buildings to be net-zero carbon. From the non-profit construction organisation's viewpoint, one representative said that the New Zealand construction industry was ready to move towards net-zero carbon target for buildings, but it required more action from the government (\#10). It was suggested that the central government could drive the implementation of zero carbon buildings in the construction industry through zero carbon policy, whilst the local government could support central government initiatives and drive change by requiring carbon reduction specifications in the consenting processes.

The problems raised here align with the principal role of government in the uptake of zero carbon buildings discussed earlier. Even though there is a strong industry engagement towards net-zero carbon buildings in New Zealand, the involvement of the government is critical. Consistent with the findings in the study of Li et al. [42], which shows that the government is the most influential entity relating to sustainable construction in China. Likewise, the authors $[43,44]$ claim that government policy instrument is the key to drive improving energy-efficiency and carbon reduction in the building sector, and incorporating several specific legal measures, especially building regulations, which control the minimum levels of carbon emission and energy performance. However, the extent to which its intervention in the form of penalties, incentives, or compensation is required in balancing the interests of other construction stakeholders presented a major challenge [42]. Therefore, further government action is needed to establish the viability of the construction industry in building for the net-zero carbon target.

\subsection{Assessment Methods and Tools}

The issue of available "assessment methods and tools" was a concern about how the construction industry addressed net-zero carbon targets for buildings. There are some assessment methods and tools used to measure the embodied and operational carbon reduction for buildings in New Zealand, broadly categorised into three groups: (1) rating systems; (2) life cycle assessment tools; (3) energy modelling tools. Rating systems include Green Star New Zealand [45]; Homestar New Zealand [46]; The Living Building Challenge and Zero carbon certification [47]; NABERSNZ [48]; Toitū carbonzero certification [49]; carboNZero Building Operations [50]. Life cycle assessment tools include LCAquick [51]; Embodied carbon database-BRANZ CO2NSTRUCT [52]; eTool [53]; OneClick LCA [54]; EC3 [55]; Tally [56]; PHRibbon [57]. Energy modelling tools include EnergyPlus [58]; IES [59]; PHPP [60]; Design Builder [61]; AccuRateNZ [62]. Summaries of rating systems and tools are demonstrated in Tables 3 and 4. 
Table 3. Summary of rating tools used within the New Zealand construction industry.

\begin{tabular}{|c|c|c|c|}
\hline No. & Rating Systems & Organisation & Function \\
\hline 1 & Green Star & NZGBC & $\begin{array}{l}\text { An internationally recognised rating system for the } \\
\text { design, construction and operation of buildings, fit-out } \\
\text { and communities. }\end{array}$ \\
\hline 2 & Home Star & NZGBC & $\begin{array}{l}\text { A dependent rating tool for assessing the health, } \\
\text { efficiency and sustainability of New Zealand's homes }\end{array}$ \\
\hline 3 & NABERSNZ & NABERSNZ & Energy rating tool for commercial buildings \\
\hline 4 & Passive house & Passive House Institute NZ & Energy performance standard \\
\hline 5 & $\begin{array}{l}\text { The Living Building } \\
\text { Challenge }\end{array}$ & $\begin{array}{l}\text { International Living Future } \\
\text { Institute (ILFI) }\end{array}$ & The world's most rigorous green building standard \\
\hline 6 & Zero carbon certification & $\begin{array}{l}\text { International Living Future } \\
\text { Institute (ILFI) }\end{array}$ & A carbon zero certification for buildings \\
\hline 7 & $\begin{array}{l}\text { carboNZero Building } \\
\text { Operations certification }\end{array}$ & NZGBC & $\begin{array}{l}\text { To help the building owners to measure current carbon } \\
\text { emissions, manage carbon footprint, offset any } \\
\text { unavoidable emissions and market success once } \\
\text { receiving carboNZero building certificate }\end{array}$ \\
\hline 8 & Toitū carbonzero certification & Toitū Envirocare & $\begin{array}{l}\text { A carbon zero certification for businesses, products } \\
\text { and services. Measure greenhouse gas emissions, and } \\
\text { put in place strategies to manage, reduce and offset }\end{array}$ \\
\hline
\end{tabular}

What stands out in Table 3 is that many different types of building standards and certifications available in the market applied in the New Zealand construction industry. Recently, New Zealand government procurement released a practical procurement guideline to reduce carbon emissions in building and construction, considering Green Star, Homestar, NABERSNZ, Passive House, Living Building Challenge and Zero Carbon Certification as official rating systems that can be used for assessing the whole of life embodied carbon or operational carbon. However, the government had no intention to endorse any particular system and this guide would be updated in the future to provide further guidance on the most appropriate system to be used [63].

There existed an unsolved problem that different organisations used different standards for buildings and the decision on which benchmarks applied for zero carbon buildings was not identified. One interviewee spoke of consideration to use certification and standards in buildings towards net-zero carbon, "We are trying to incorporate the best practice and just deciding what makes the most sense from a certification" (\#3). Participant \#2 mentioned the consideration of building certifications and standards but indicated that all the current assessment methods could be used to measure carbon reduction for buildings, " . . they are all targeted or at least start to measure getting to net-zero carbon". Notwithstanding, another participant believed that only Living Building Challenge certification could be applied for zero carbon buildings, "There's only one zero carbon building in New Zealand that is a certificated Living Building Challenge" (\#4).

This finding raises questions about the misinterpretation of carbon performance of New Zealand's buildings due to the result of carbon auditing, and benchmarking generated by different rating tools might vary significantly. For Greenstar certification, up to 20 points are awards across greenhouse gas emission credit, where it is estimated that the greenhouse gas emission figures are considerably lower than a standard building [45]. While Living Building Challenge offers two levels of carbon certifications, including zero carbon and net carbon positive [64]. The result is in line with $\mathrm{Ng}$ et al.'s [65] findings which have shown that the baseline carbon emission rates of building environmental assessment tools differ noticeably, leading to the impact on the carbon auditing outcomes and the perception of how "low carbon" the assessed building is. 
Table 4. Summary of LCA and energy modelling tools used within the New Zealand construction industry.

\begin{tabular}{|c|c|c|c|}
\hline No. & Tools & Organisation & Function \\
\hline 1 & LCAquick & $\begin{array}{l}\text { Building Research Association } \\
\text { of New Zealand (BRANZ) }\end{array}$ & $\begin{array}{l}\text { To conduct a life cycle assessment (LCA) and understand } \\
\text { the potential environmental impacts of a building design } \\
\text { across the life cycle }\end{array}$ \\
\hline 2 & BRANZ $\mathrm{CO}_{2} \mathrm{NSTRUCT}$ & $\begin{array}{l}\text { Building Research Association } \\
\text { of New Zealand (BRANZ) }\end{array}$ & $\begin{array}{c}\text { To provide embodied carbon and energy values for } \\
\text { building materials, including concrete, glass, timber and } \\
\text { metals, as well as products such as bathroom and kitchen } \\
\text { fittings and lifts }\end{array}$ \\
\hline 3 & eTool & eTool Global & $\begin{array}{l}\text { Life cycle assessment (LCA) software for buildings and } \\
\text { infrastructure }\end{array}$ \\
\hline 4 & OneClick LCA & $\begin{array}{l}\text { Bionova Ltd. (Helsinki, } \\
\text { Finland) }\end{array}$ & $\begin{array}{l}\text { Life cycle assessment software that helps calculate and } \\
\text { reduce the environmental impacts of building and } \\
\text { infrastructure projects, products and portfolio }\end{array}$ \\
\hline 5 & EC3 & $\begin{array}{l}\text { Life Cycle Association of New } \\
\text { Zealand (LCANZ) }\end{array}$ & Embodied Carbon in Construction Calculator (EC3) Tool \\
\hline 6 & Tally & AUTODESK & $\begin{array}{l}\text { An Autodesk Revit application that allows architects and } \\
\text { engineers to quantify the environmental impact of } \\
\text { building materials for whole building analysis as well as } \\
\text { comparative analyses of design options }\end{array}$ \\
\hline 7 & PHRibbon & AECB PHribbon & $\begin{array}{l}\text { Carbon calculations for Passivhaus and low energy } \\
\text { buildings including retrofits }\end{array}$ \\
\hline 8 & EnergyPlus & $\begin{array}{c}\text { U.S. Department of Energy's } \\
\text { (DOE) Building Technologies } \\
\text { Office (BTO) and National } \\
\text { Renewable Energy Laboratory } \\
\text { (NREL) }\end{array}$ & $\begin{array}{c}\text { A whole building energy simulation program that } \\
\text { engineers, architects, and researchers use to model both } \\
\text { energy consumption-for heating, cooling, ventilation, } \\
\text { lighting and plug and process loads-and water use in } \\
\text { buildings }\end{array}$ \\
\hline 9 & IES & IES-VE & $\begin{array}{l}\text { Whole building energy simulation analysis that covers a } \\
\text { wide range of assessment types from energy efficiency, } \\
\text { comfort, ventilation, HVAC performance and optimisation }\end{array}$ \\
\hline 10 & PHPP & Passive House Institute NZ & $\begin{array}{c}\text { Model the performance of a Passive House design for } \\
\text { compliance with the Passive House Standard and } \\
\text { submission for Certification }\end{array}$ \\
\hline 11 & Design Builder & Design Builder & $\begin{array}{l}\text { The most established and advanced user interface to } \\
\text { EnergyPlus }\end{array}$ \\
\hline 12 & AccuRateNZ & $\begin{array}{l}\text { CSIRO (Australia's national } \\
\text { science agency) }\end{array}$ & Thermal simulation \\
\hline
\end{tabular}

Looking at Table 4, the problem occurred again due to many design support tools which are available within the New Zealand construction industry, highlighting the need for further government guidance on the most appropriate systems and tools to be applied as discussed earlier [63]. There is also a lack of evidence that demonstrates the accurate calculation of carbon reduction when applying some global tools in the New Zealand case, as the environmental impacts and material databases vary from one country to another. In terms of life cycle assessment tools, LCAQuick is one of the free tools developed by the Building Research Association of New Zealand that help architects, designers, and structural engineers to calculate the carbon performance (both operational and embodied carbon) for low carbon design decisions for buildings. The tools are successful as they are able to provide an accurate building database and evaluate carbon footprint and other environmental impacts of building designs in New Zealand. There is also potential to integrate the climate target and carbon budget mentioned above into these tools [27]. Likewise, eTool is suggested to apply for New Zealand's buildings by the Building Research Association of New Zealand because it is set up with a localised life cycle assessment 
database for New Zealand [66]. Such approaches should be promoted broadly within the construction industry as platforms to stimulate the continuous construction innovation and the development of zero carbon buildings.

\section{Discussion}

The research reported in this paper has critically examined the current practices towards zero carbon buildings in New Zealand. The most obvious finding to emerge from the analysis above is the significant influence of the government in the uptake of zero carbon buildings in New Zealand. This leads to a deeper explanation of the government role and policy implications in improving the present application of zero carbon buildings.

New Zealand's government response to climate change is advancing, however, there is late adoption of the Zero Carbon Act in the construction industry. In 1997, a 2012 greenhouse gas emissions target "net emissions equal to 1990 gross emissions" was introduced, aligning with the Kyoto Conference of the Parties (COP). Until 2019, the latest amendment was approved in the Climate Change Response Act 2002, with a commitment to reduce greenhouse gas emissions to zero by 2050 [67]. Compared to other developed countries such as the UK, which assented the Climate Change Act in 2008 with mandated specific carbon-reduction budgets [68], New Zealand only launched a Zero Carbon Bill 10 years later, that outlined a plan to reduce greenhouse gas emissions and established an independent Climate Change Commission to review the target under certain conditions [69].

The late promotion of zero carbon-related legislation leads to the delay of zero carbon policies for New Zealand's buildings. To date, the building code possesses no requirement for zero carbon buildings [70]. None of the policy documents for zero carbon buildings are officially formulated and implemented as the government's climate change programme for buildings mentioned above has launched in late 2020 and just finished the consultation process. Therefore, the government needs to rapidly establish a pathway for achieving zero carbon buildings in building regulation and guidelines. Lagging behind other developed countries has given New Zealand a considerable opportunity to identify lessons learned in the local context. An insight gained from the UK case study is that instead of requiring the construction industry to build zero carbon buildings at first, which is beyond the industry workability, one of the "allowable solutions" is to mandate markedly increased levels of energy efficiency as the basis of the "zero carbon" policy for building [71]. More importantly, New Zealand has a green electricity grid and it is anticipated to be $100 \%$ sourced from renewable energy by 2030 [70,72], therefore, the central focus should be on minimising embodied carbon emission from materials and products rather than improving energy efficiency. These findings have vital implications for developing strategies for implementing net-zero carbon buildings in New Zealand.

To allow New Zealand's construction industry to build zero carbon buildings, the government must mandate net-zero carbon policies by upgrading the building code and regulations. Commenting on the importance of the building code in improving energy efficiency, the United Nations Environment Program (UNEP) and the International Energy Agency (IEA) have indicated that energy efficiency requirements in the building code to be among the most critical determinants of a building's energy efficiency [73,74]. Concerning zero carbon buildings, such energy efficiency strategies can be included in the building codes to reduce operational carbon emissions, accompanied by the requirement of using low-carbon materials to decrease embodied carbon emissions for buildings. Moreover, enforcing building rating systems and carbon calculation tools is also a potential solution to standardise the carbon measurement scale and audit, creating synchronism for the entire construction industry. This finding agrees with studies $[75,76]$, recommending that the government should incorporate a sustainability rating tool and set minimum standards in the New Zealand building code. In summary, an overarching government policy such as well-designed and implemented building codes, regulations and appliance standards is the most effective emission reduction instrument. 
Central and local governments can encourage the construction industry to reduce greenhouse gas emissions in building projects by leading by example. As described above, the public sector is required to be carbon neutral by 2025 and the government agencies have leaderships in advocating carbon emissions in public buildings. However, the focus is on existing government office buildings for lease only, despite the fact that there is a large number of public buildings, which are not considered to be built towards net-zero carbon. It is recommended that the government should lead by example and establish zero carbon policy to transiting the entire public building stock to net-zero carbon. The result is in line with the study of [76], confirming the substantial contribution of the public sector to driving changes in the construction industry. This study indicates that central and local governments are the most effective driving forces for encouraging sustainable housing in New Zealand.

\section{Conclusions}

The present study has revealed the current application of zero carbon buildings in New Zealand, with regard to the government and building professionals' perspectives. One of the more significant findings is that the central and local government's initiatives on zero carbon buildings are underway, including revising building policies and regulations and requiring the carbon-neutral for public buildings by 2025. Building specialists support the idea that the building sector should move towards net-zero carbon and engage themselves in maximising the carbon reductions for their building projects. The research has also revealed the differences in the carbon performance of New Zealand's buildings because of the use of different rating systems and calculating tools. This leads to the impact on the distinct carbon measurement and auditing outcomes and the misperception of setting zero carbon targets for buildings.

The evidence from this study suggests that New Zealand's construction industry is still in the early stage of transiting to net-zero carbon built environment and further works need to be done in the near future. The analysis highlights the importance of the government's role and provides policy recommendations for improving zero carbon building practices. The government should formulate building policies and regulations and take leadership in implementing zero carbon building. This research is the first acrossthe-board investigation of the zero carbon building practices in New Zealand. The study addresses the current practices and policy implications. Net-zero carbon target for buildings can be achieved through adopting not only well-defined and deliberate building policies, but also integrated building design process, knowledge sharing and the collaboration among building stakeholders with available resources and support mechanisms. This would be a fruitful area for the future work. The study is also limited by the lack of information on the views of building contractors, who accomplish the construction work activities and ensure the building project zero carbon-delivered. The small sample size also did not allow to confirm wider building practitioners' viewpoints. Further studies with a larger sample size, such as conducting a survey with New Zealand's building professionals, need to be carried out to validate these findings. Notwithstanding these limitations, the research results add to the rapidly expanding field of zero carbon building research internationally, by shedding new light on the New Zealand case.

Author Contributions: Conceptualization, T.T.P.B.; methodology, T.T.P.B., S.W., N.D. and C.M.; validation, S.W., N.D. and C.M.; formal analysis, T.T.P.B.; investigation, T.T.P.B.; resources, T.T.P.B.; data curation, T.T.P.B.; writing-original draft preparation, T.T.P.B.; writing-review and editing, S.W., N.D. and C.M.; visualization, T.T.P.B.; supervision, S.W., N.D. and C.M. All authors have read and agreed to the published version of the manuscript.

Funding: This research received no external funding.

Institutional Review Board Statement: The study was conducted according to the guidelines of Massey University, New Zealand and approved by Massey University Human Ethics Committee (protocol code: 4000023526; date of approval: 19 October 2020). 
Informed Consent Statement: Informed consent was obtained from all subjects involved in the study.

Data Availability Statement: The data presented in this study are available on request from the corresponding author. The data are not publicly available due to privacy and ethical restrictions.

Acknowledgments: This work is part of a Ph.D. research project supported with a Doctoral Scholarship by Massey University, New Zealand. The authors gratefully acknowledge Massey University and the Building Research Association of New Zealand (BRANZ) for their support. The authors would like to express special thanks to all interviewees who take part in this research.

Conflicts of Interest: The authors declare no conflict of interest.

\section{References}

1. Niamir, L.; Kiesewetter, G.; Wagner, F.; Schöpp, W.; Filatova, T.; Voinov, A.; Bressers, H. Assessing the macroeconomic impacts of individual behavioral changes on carbon emissions. Clim. Chang. 2020, 158, 141-160. [CrossRef]

2. Rogelj, J.; Luderer, G.; Pietzcker, R.C.; Kriegler, E.; Schaeffer, M.; Krey, V.; Riahi, K. Energy system transformations for limiting end-of-century warming to below $1.5^{\circ} \mathrm{C}$. Nat. Clim. Chang. 2015, 5, 519-527. [CrossRef]

3. Ministry of the Environment. Climate Change Response (Zero Carbon) Amendment Act. Available online: Mfe.govt.nz/climatechange/zero-carbon-amendment-act (accessed on 5 November 2020).

4. United Nations. Buildings and Climate Change: Summary for Decision-Makers; United Nations Environmental Programme, Sustainable Buildings and Climate Initiative: Paris, France, 2009; pp. 1-62.

5. IPCC. Climate Change 2014: Synthesis Report. Contribution of Working Groups I, II and III to the Fifth Assessment Report of the Intergovernmental Panel on Climate Change; IPCC: Geneva, Switzerland, 2014.

6. Pearce, A.R.; Ahn, Y.H. Sustainable Buildings and Infrastructure: Paths to the Future; Routledge: Abingdon, UK, 2017.

7. Ministry of Business Innovation and Employment (MBIE). Building for Climate Change: Transforming Operational Efficiency and Reducing Whole-of-Life Embodied Carbon. Available online: https:/ / www.mbie.govt.nz/have-your-say/building-for-climatechange-transforming-operational-efficiency-and-reducing-whole-of-life-embodied-carbon/ (accessed on 5 November 2020).

8. Jones, P. A 'smart' bottom-up whole-systems approach to a zero-carbon built environment. Build. Res. Inf. 2018, 46, 566-577. [CrossRef]

9. Pan, M.; Pan, W. Knowledge, attitude and practice towards zero carbon buildings: Hong Kong case. J. Clean. Prod. 2020, 274, 122819. [CrossRef]

10. Jones, P.; Hou, S.S.; Li, X. Towards zero carbon design in offices: Integrating smart facades, ventilation, and surface heating and cooling. Renew. Energy 2015, 73, 69-76. [CrossRef]

11. Moschetti, R.; Brattebø, H.; Sparrevik, M. Exploring the pathway from zero-energy to zero-emission building solutions: A case study of a Norwegian office building. Energy Build. 2019, 188-189, 84-97. [CrossRef]

12. Pan, W. System boundaries of zero carbon buildings. Renew. Sustain. Energy Rev. 2014, 37, 424-434. [CrossRef]

13. Pan, W.; Li, K. Clusters and exemplars of buildings towards zero carbon. Build. Environ. 2016, 104, 92-101. [CrossRef]

14. Zhao, X.; Hwang, B.-G.; Lu, Q. Typology of business model innovations for delivering zero carbon buildings. J. Clean. Prod. 2018, 196, 1213-1226. [CrossRef]

15. Saunders, M.; Lewis, P.; Thornhill, A. Research Methods for Business Students, 7th ed.; Pearson Education: London, UK, 2016.

16. Gray, D.E. Doing Research in the Real World, 4th ed.; SAGE: Thousand Oaks, CA, USA, 2018.

17. Robinson, O.C. Sampling in Interview-Based Qualitative Research: A Theoretical and Practical Guide. Qual. Res. Psychol. 2014, 11, 25-41. [CrossRef]

18. Teddlie, C.; Yu, F. Mixed methods sampling: A typology with examples. J. Mix. Methods Res. 2007, 1, 77-100. [CrossRef]

19. Albrecht, W.D. LinkedIn for accounting and business students. Am. J. Bus. Educ. 2011, 4, 39-42. [CrossRef]

20. Creswell, J.W.; Poth, C.N. Qualitative Inquiry and Research Design: Choosing among Five Approaches; Sage Publications: Thousand Oaks, CA, USA, 2016.

21. Francis, J.J.; Johnston, M.; Robertson, C.; Glidewell, L.; Entwistle, V.; Eccles, M.P.; Grimshaw, J.M. What is an adequate sample size? Operationalising data saturation for theory-based interview studies. Psychol. Health 2010, 25, 1229-1245. [CrossRef]

22. Flick, U. An Introduction to Qualitative Research, 6th ed.; SAGE Publications Ltd.: Thousand Oaks, CA, USA, 2018.

23. Clarke, V.; Braun, V. Thematic analysis. In Encyclopedia of Critical Psychology; Springer: Berlin/Heidelberg, Germany, 2014; pp. 1947-1952.

24. Bazeley, P.; Jackson, K. Qualitative Data Analysis with NVivo; SAGE Publications Ltd: Thousand Oaks, CA, USA, 2013.

25. Hoover, R.S.; Koerber, A.L. Using NVivo to answer the challenges of qualitative research in professional communication: Benefits and best practices tutorial. IEEE Trans. Prof. Commun. 2009, 54, 68-82. [CrossRef]

26. Riedy, C.; Lederwasch, A.; Ison, N. Defining Zero Emission Buildings-Review and Recommendations: Final Report; Prepared for Australian Sustainable Built Environment Council by the Institute for Sustainable Futures; University of Technology: Sydney, Australia, 2011. 
27. Chandrakumar, C.; McLaren, S.J.; Dowdell, D.; Jaques, R. A science-based approach to setting climate targets for buildings: The case of a New Zealand detached house. Build. Environ. 2020, 169. [CrossRef]

28. Building Research Association of New Zealand (BRANZ). Building LCA/Carbon Footprint. Available online: https://www. branz.co.nz/pubs/case-studies/lcaquick/ (accessed on 26 March 2021).

29. Röck, M.; Saade, M.R.M.; Balouktsi, M.; Rasmussen, F.N.; Birgisdottir, H.; Frischknecht, R.; Habert, G.; Lützkendorf, T.; Passer, A. Embodied GHG emissions of buildings-The hidden challenge for effective climate change mitigation. Appl. Energy 2020, 258. [CrossRef]

30. Moncaster, A.M.; Rasmussen, F.N.; Malmqvist, T.; Houlihan Wiberg, A.; Birgisdottir, H. Widening understanding of low embodied impact buildings: Results and recommendations from 80 multi-national quantitative and qualitative case studies. J. Clean. Prod. 2019, 235, 378-393. [CrossRef]

31. New Zealand Government. Public Sector to Be Carbon Neutral by 2025. Available online: https://www.beehive.govt.nz/release/ public-sector-be-carbon-neutral-2025 (accessed on 26 March 2021).

32. Radio New Zealand (RNZ). Is a Carbon Neutral Public Sector Achievable by 2025? Available online: https://www.rnz.co. $\mathrm{nz} /$ national/programmes/ninetonoon/audio/2018777070/is-a-carbon-neutral-public-sector-achievable-by-2025 (accessed on 26 March 2021).

33. Ball, A.; Mason, I.; Grubnic, S.; Hughes, P. The Carbon Neutral Public Sector. Public Manag. Rev. 2009, 11, 575-600. [CrossRef]

34. Lai, X.; Liu, J.; Shi, Q.; Georgiev, G.; Wu, G. Driving forces for low carbon technology innovation in the building industry: A critical review. Renew. Sustain. Energy Rev. 2017, 74, 299-315. [CrossRef]

35. Liu, W.; Qin, B. Low-carbon city initiatives in China: A review from the policy paradigm perspective. Cities 2016, 51, 131-138. [CrossRef]

36. Zhang, L.; Li, Q.; Zhou, J. Critical factors of low-carbon building development in China's urban area. J. Clean. Prod. 2017, 142, 3075-3082. [CrossRef]

37. Birchall, S.J. Carbon management in New Zealand local government: Co-benefits of action and organisational resolve in the absence of government support. Australas. J. Environ. Manag. 2014, 21, 253-267. [CrossRef]

38. Kesidou, S.L.; Sorrell, S. Low-carbon innovation in non-domestic buildings: The importance of supply chain integration. Energy Res. Soc. Sci. 2018, 45, 195-213. [CrossRef]

39. Enker, R.A.; Morrison, G.M. Analysis of the transition effects of building codes and regulations on the emergence of a low carbon residential building sector. Energy Build. 2017, 156, 40-50. [CrossRef]

40. Giesekam, J.; Barrett, J.R.; Taylor, P. Construction sector views on low carbon building materials. Build. Res. Inf. 2016, 44, 423-444. [CrossRef]

41. Killip, G. Products, practices and processes: Exploring the innovation potential for low-carbon housing refurbishment among small and medium-sized enterprises (SMEs) in the UK construction industry. Energy Policy 2013, 62, 522-530. [CrossRef]

42. Li, H.; Zhang, X.; Ng, S.T.; Skitmore, M. Quantifying stakeholder influence in decision/evaluations relating to sustainable construction in China-A Delphi approach. J. Clean. Prod. 2018, 173, 160-170. [CrossRef]

43. Zhang, Y.; Wang, Y. Barriers' and policies' analysis of China's building energy efficiency. Energy Policy 2013, 62, 768-773. [CrossRef]

44. Li, J.; Colombier, M. Managing carbon emissions in China through building energy efficiency. J. Environ. Manag. 2009, 90, 2436-2447. [CrossRef] [PubMed]

45. New Zealand Green Building Council (NZGBC). History of Green Star. Available online: https://www.nzgbc.org.nz/Category? Action=View\&Category_id=293 (accessed on 3 March 2021).

46. New Zealand Green Building Council (NZGBC). Homestar. Available online: https://www.nzgbc.org.nz/homestar (accessed on 3 March 2021).

47. International Living Future Institue (ILFI). Living Building Challenge. Available online: https://living-future.org/lbc/ (accessed on 3 March 2021).

48. NABERSNZ. About NABERSNZ. Available online: https://www.nabersnz.govt.nz/about-nabersnz/background/ (accessed on 3 March 2021).

49. Toitū Envirocare. Carbon Programmes \& Certification. Available online: https://www.toitu.co.nz/what-we-offer/carbonmanagement (accessed on 3 March 2021).

50. New Zealand Green Building Council (NZGBC). carboNZero Building Operations. Available online: https://www.nzgbc.org. nz/zerocarbon/buildingoperations (accessed on 3 March 2021).

51. Building Research Association of New Zealand (BRANZ). LCAQuick: Life Cycle Assessment Tool. Available online: https: //www.branz.co.nz/environment-zero-carbon-research/framework/lcaquick/ (accessed on 12 March 2021).

52. Building Research Association of New Zealand (BRANZ). BRANZ $\mathrm{CO}_{2}$ NSTRUCT. Available online: https://www.branz.co.nz/ environment-zero-carbon-research/framework/branz-co2nstruct/ (accessed on 12 March 2021).

53. eToolLCD. eTool. Available online: https:/ / etoolglobal.com/ (accessed on 12 March 2021).

54. Bianova Ltd. One Click LCA. Available online: https:/ / www.oneclicklca.com/ (accessed on 15 June 2021).

55. Life Cycle Association of New Zealand (LCANZ). Embodied Carbon in Construction Calculator (EC3) Tool. Available online: https:/ / lcanz.org.nz/2020/04/24/embodied-carbon-in-construction-calculator-ec3-tool/ (accessed on 15 June 2021). 
56. AUTODESK. Tally. Available online: https://apps.autodesk.com/RVT/en/Detail/Index?id=3841858388457011756\&appLang= en\&os=Win64 (accessed on 15 June 2021).

57. AECB PHribbon. PHribbon. Available online: https://www.phribbon.co.uk/ (accessed on 15 June 2021).

58. National Renewable Energy Laboratory (NREL). EnergyPlus. Available online: https://energyplus.net/ (accessed on 15 June 2021).

59. IES. IES Energy Modeling Software. Available online: https:/ /www.iesve.com/software/building-energy-modeling (accessed on 15 June 2021).

60. Passive House Institute NZ (PHINZ). PHPP 9.6. Available online: https:/ / passivehouse.nz/product/phpp-9--6/ (accessed on 15 June 2021).

61. DesignBuilder. EnergyPlus Simulation. Available online: https:/ / designbuilder.co.uk/simulation (accessed on 15 June 2021).

62. Building Research Association of New Zealand (BRANZ). Level-The Authority of Sustainable Buildings. Available online: http:/ / www.level.org.nz/passive-design/thermal-simulation/ (accessed on 15 June 2021).

63. New Zealand Government Procurement. Procurement Guide to Reducing Carbon Emissions in Building and Construction: A Practical Guide. Available online: https:/ / www.procurement.govt.nz/assets/procurement-property/documents/procurementguide-to-reducing-carbon-emissions-in-building-and-construction.pdf (accessed on 15 June 2021).

64. International Living Future Institue (ILFI). Living Building Challenge 4.0: A Visionary Path to a Regenerative Future. Available online: https: / living-future.org/lbc/ (accessed on 26 March 2021).

65. Ng, S.T.; Chen, Y.; Wong, J.M.W. Variability of building environmental assessment tools on evaluating carbon emissions. Environ. Impact Assess. Rev. 2013, 38, 131-141. [CrossRef]

66. Jaques, R. Measuring Our Sustainability Progress: New Zealand's New Detached Residential Housing Stock (First Update). BRANZ Study Report SR426. Available online: https://www.branz.co.nz/pubs/research-reports/sr426/ (accessed on 15 June 2021).

67. New Zealand Legislation. Climate Change Response (Zero Carbon) Amendment Act 2019. Available online: https://www. legislation.govt.nz/act/public/2019/0061/latest/LMS183736.html (accessed on 12 July 2021).

68. Climate Change Act. Climate Change Act 2008. Available online: https://www.legislation.gov.uk/ukpga/2008/27/contents (accessed on 12 July 2021).

69. Ministry for the Environment. Climate Change Response Zero Carbon Amendment Bill: Summary. Available online: https: / / environment.govt.nz/publications/climate-change-response-zero-carbon-amendment-bill-summary/ (accessed on 12 July 2021).

70. MacGregor, C.; Dowdell, D.; Jaques, R.; Bint, L.; Berg, B. The Built Environment and Climate Change: A Review of Research, Challenges and the Future; SR403; BRANZ Ltd.: Judgeford, New Zealand, 2018.

71. McLeod, R.S.; Hopfe, C.J.; Rezgui, Y. An investigation into recent proposals for a revised definition of zero carbon homes in the UK. Energy Policy 2012, 46, 25-35. [CrossRef]

72. Ardern, J. 100\% Renewable Electricity Generation by 2030. Available online: https:/ / www.labour.org.nz/release-renewableelectricity-generation-2030 (accessed on 21 March 2021).

73. UNEP. Assessment of Instruments forReducing Greenhouse Gas Emissions from Buildings; United Nations Environment Program: Paris, France, 2007.

74. Laustsen, J. Energy Efficiency Requirements in Building Codes, Energy Efficiency Policies for New Buildings; IEA Information Paper; IEA: Paris, France, 2008.

75. Clark, M. National Value Case for Sustainable Housing Innovations; Publication PR240/4 for Beacon Pathway; Beacon Pathway Ltd.: Auckland, New Zealand, 2007.

76. Li, X.; Liu, Y.; Wilkinson, S.; Liu, T. Driving forces influencing the uptake of sustainable housing in New Zealand. Eng. Constr. Archit. Manag. 2019, 26, 46-65. [CrossRef] 